PROFESI (Profesional Islam): Media Publikasi Penelitian

2019; Volume 16; No 2.

Website: ejournal.stikespku.ac.id

\title{
Pengaruh Berkumur Air Kelapa Muda Terhadap Penurunan Skor Mukositis Akibat Kemoterapi Pada Anak
}

\author{
Gatot Suparmanto $^{1^{*}}$, Setiyawan ${ }^{2}$ \\ ${ }^{1,2}$ Prodi Sarjana Keperawatan, STIKes Kusuma Husada Surakarta \\ *Email: stikes_kh@yahoo.com
}

\begin{abstract}
Kata Kunci
Air Kelapa

Muda,

Oral Care,

Kemoterapi,

Mukositis
\end{abstract}

Abstrak

\begin{abstract}
Kemoterapi merupakan salah satu penatalaksanaan pasien kanker. Namun, obat kemoterapi dapat merusak sel mukosa normal, menyebabkan inflamasi, pembentukan lesi dan ulserasi sehingga mencetuskan cedera sel mukosa (mukositis). Reaktivitas radikal bebas akibat kemoterapi dapat dihambat oleh sistem antioksidan yang terdapat pada sayuran dan buah-buahan.Berkumur air kelapa muda direkomen-dasikan dalam tindakan oral care. Penelitian ini bertujuan untuk mengetahui pengaruh berkumur air kelapa muda terhadap mukositis akibat kemoterapi pada pasien anak. Penelitian kuantitatif pre test post test control group design dengan instrumen Oral Assasment Guide pada 15 responden kelompok intervensi dan 15 responden kelompok kontrol dengan teknik simple random sampling. Hasil uji statistik paired t-test menunjukkan terdapat penurunan yang signifikan pada rerata skor mukositis setelah intervensi pada kelompok intervensi ( $p=0.000)$. Peneliti menyim-pulkan berkumur air kelapa muda dalam tindakan oral care dapat menurunkan mukositis akibat kemoterapi, sehingga diharapkan hasil penelitian ini dapat diaplikasikan dalam protokol oral care pada anak yang menjalani kemoterapi sebagai bagian dari penerapan ilmu komplementer.
\end{abstract}

\section{The Effect of Gargling Young Coconut Water on Mukositis Score Due To Chemotherapy On Pediatrie Patients}

\author{
Key Words: \\ Young Coconut \\ Water, \\ Oral Care, \\ Chemotherapy, \\ Mukositis
}

\begin{abstract}
Chemotherapy is one of the management of cancer patients. However, chemotherapy drugs can damage normal mucosal cells, causing inflammation, formation of lesions and ulceration, triggering mucosal cell injury (mucositis). The reactivity of free radicals due to chemotherapy can be inhibited by an antioxidant system found in vegetables and fruits. Gargling young coconut water is recommended in the oral care. The aim of this study is to determine the effect of gargling young coconut water on mucositis due to chemotherapy on pediatric patients. This research was quantitative research pre-test post test control group design with the Oral Assistance Guide instrument in with 15 respondents in the intervention group and 15 respondents in the control group with simple random sampling technique. The results of the paired t-test statistical test showed that there was a significant decrease in the mean of mucositis score after intervention in the intervention group $(p=0.000)$. Researchers concluded that gargling of young coconut water in the oral care can reduce mucositis due to chemotherapy, so that the results of this study can be applied in the oral care protocol for children undergoing chemotherapy as part of the application of complementary science.
\end{abstract}




\section{PENDAHULUAN}

Kanker anak harus ditangani secara berkualitas untuk mengendalikan jumlah dan penyebaran sel-sel kanker. Menurut Hockenberry dan Wilson (2009), kemoterapi efektif untuk menangani kanker pada anak. Selain memiliki efek terapeutik yang mengambat pertumbuhn sel kanker, kemoterapi juga memiliki efek samping yang berbahaya dan memerlukan penanganan. Efek samping yang banyak ditemukan pada anak yang mendapat kemoterapi adalah depresi sumsung tulang, diare, kehilangan rambut, masalahmasalah kulit, mual, muntah serta gangguan kesehatan mulut yaitu mukositis (CCNS, 2008).

Mukositis akibat kemoterapi meyebabkan terjadinya berbagai konsekuensi. Depkes, (2011) menyatakan bahwa anak dengan mukositis memerlukan penyesuaian dosis kemoterapi. Hal ini dapat memperpanjang penatalaksanaan kanker sehingga perawatan menjadi lebih lama, meningkatkan pembiayaan serta menurunkan kualitas hidup anak.

Telah banyak tindakan yang dilakukan untuk mengatasi efek radikal dari obat kemoterapi tersebut, baik tindakan medis maupun tindakan keperawatan untuk menangani mukositis. Intervensi keperawatan penanganan mukositis diantaranya adalah oral care yang berkualitas, pemberian agen antiseptic, pembersihan mulut (multiagen mouthwashes), agen anti inflamasi, growth factor, cytokine-like agent serta berbagai agen lainnya (Keefe et al., 2007). Saat ini belum ada kesepakatan mengenai intervensi yang menjadi standar untuk menangani mukositis akibat kemoterapi dan belum ditemukan zat yang dapat menangani mukositis pada pasien kanker (Mottalebnejad, 2008).

Berdasarkan literatur yang telah dipelajari menyebutkan bahwa efek radikal bebas akibat kemoterapi dapat dihambat oleh sistem antioksidan yang dapat diperoleh melalui sayuran dan buah-buahan yang mengandung antioksidan tinggi. Penggunaan makanan dan nutraceutical merupakan salah satu terapi komplementer dan sesuai dengan teori keperawatan Florence Nigtingale. Dalam konsep nutraceutical diyakini bahwa makanan atau bagian dari makanan memberikan manfaat bagi kesehatan dan dapat digunakan sebagai obat, termasuk sebagai pencegahan terhadap penyakit (Nursing, 2006).
Salah satu sumber makanan yang termasuk nutraceutical adalah air kelapa muda. Penelitianpenelitian yang sudah ada menyebutkan bahwa berkumur air kelapa muda berpengaruh dalam menurunkan $\mathrm{pH}$ saliva. Saliva merupakan salah satu faktor yang berperan dalam mengontrol $\mathrm{pH}$ rongga mulut terhadap pertumbuhan parasit atau mikroba (Mokoginta, Wowor, Juliatri, 2017). Air kelapa muda mempunyai efek terapeutik yaitu sebagai minuman steril, yang mengandung antioksidan, anti inflamasi dan mineral berupa kalium, natrium, kalsium serta vitamin $\mathrm{C}$ yang menyebabkan bakteri sulit hidup pada kondisi ini (Runtunuwu, 2011; Yanwar dan Sutrisno, 2015).

Berdasarkan latar belakang tersebut diatas, maka pertanyaan dalam penelitian ini adalah bagaimana pengaruh berkumur air kelapa muda terhadap mukositis akibat kemoterapi pada anak. Tujuan dari penelitian ini adalah mengetahui pengaruh berkumur air kelapa muda terhadap mukositis akibat kemoterapi pada anak.

\section{METODE}

Penelitian ini merupakan penelitian kuantitatif dengan design pre dan post test group with control. Penelitian ini dilakukan di RSUD dr. Moewardi. Sampel pada penelitian ini adalah 15 responden pada kelompok intervensi dan 15 responden pada kelompok kontrol dengan menggunakan teknik simple random sampling.

Instrumen yang digunakan dalam pengumpulan data menggunakan ceklist data demografi dan hasil pengukuran skor mukositis responden menggunakan kuesioner Oral Assesment Guide $(O A G)$. Pemberian perlakuan dengan berkumur air kelapa muda dilakukan pada kelompok intervensi yaitu mendapatkan tindakan keperawatan oral care dan berkumur air kelapa muda. Setiap hari dilakukan 3 kali oral care, yaitu setiap 30 (tiga puluh) menit setelah makan pagi, makan siang, makan malam, selama 5 hari. Analisis data menggunakan uji paired t-test dengan tingkat kepercayaan $95 \%$ untuk mengetahui pengaruh berkumur air kelapa muda terhadap skor mukositis pasien anak dengan kemoterapi.

\section{HASIL DAN PEMBAHASAN} 3.1 Analisis Univariat

Hasil analisis univariat karakteristik responden mendiskripsikan karakteristik masing-masing variabel yang diteliti yaitu pengalaman mukositis 
PROFESI (Profesional Islam): Media Publikasi Penelitian 2019; Volume 16; No 2.

Website: ejournal.stikespku.ac.id

sebelumnya, jenis kemoterapi, status gizi dan skor mukositis sebelum dan setelah intervensi adalah sebagai berikut:

Tabel 1. Distribusi Responden $\left(\mathrm{n}_{1}-\mathrm{n}_{2}: 15\right)$

\begin{tabular}{lcccccc}
\hline Variabel & \multicolumn{2}{c}{ Kontrol } & \multicolumn{2}{c}{ Intervensi } & \multicolumn{2}{c}{ Total } \\
\cline { 2 - 7 } & $\mathrm{f}$ & $\%$ & $\mathrm{f}$ & $\%$ & $\mathrm{f}$ & $\%$ \\
\hline $\begin{array}{l}\text { Pengalaman } \\
\text { Mukositis }\end{array}$ & 10 & 66.7 & 12 & 80 & 22 & 73 \\
$\begin{array}{l}\text { Ada riwayat } \\
\text { Tidak ada }\end{array}$ & 5 & 33.3 & 3 & 20 & 8 & 27 \\
riwayat & & & & & & \\
\hline Jenis & & & & & & \\
Kemoterapi & 4 & 6.7 & 5 & 33.3 & 9 & 30 \\
Mukosatoksi & 11 & 93.3 & 10 & 66.7 & 21 & 70 \\
k sedang & & & & & & \\
$\begin{array}{l}\text { Mukosatoksi } \\
\text { k tinggi }\end{array}$ & & & & & & \\
\hline $\begin{array}{l}\text { Status Gizi } \\
\text { Normal }\end{array}$ & 8 & 53.3 & 8 & 53.3 & 16 & 53.3 \\
Tidak & 7 & 46.7 & 7 & 46.7 & 14 & 46.7 \\
Normal & & & & & & \\
\hline
\end{tabular}

Tabel 2. Distribusi Responden Berdasarkan Skor Mukositis Sebelum Intervensi $\left(\mathrm{n}_{1}-\mathrm{n}_{2}: 15\right)$

\begin{tabular}{lcccc}
\hline Variabel & Mean & SD & Min-Mak & $95 \%$ CI \\
\hline Skor & & & & \\
Mukositis & 8.80 & 0.62 & $8-10$ & $8.55-9.09$ \\
- Intervensi & 8.91 & 0.64 & $8-10$ & $8.65-9.20$ \\
- Kontrol & & & & \\
\hline
\end{tabular}

Tabel 3. Distribusi Responden Berdasarkan Skor Mukositis Setelah Intervensi $\left(\mathrm{n}_{1}-\mathrm{n}_{2}: 15\right)$

\begin{tabular}{lcccc}
\hline Variabel & Mean & SD & $\begin{array}{c}\text { Min- } \\
\text { Mak }\end{array}$ & $95 \%$ CI \\
\hline Skor & & & & \\
Mukositis & 8.27 & 0.54 & $8-9$ & $8.20-8.62$ \\
- Intervensi & 12.82 & 1.46 & $11-16$ & $12.12-13.31$ \\
- Kontrol & & & & \\
\hline
\end{tabular}

Pada tabel 1. menunjukkan bahwa hampir seluruh responden pada kelompok intervensi maupun kelompok kontrol memiliki riwayat pengalaman mukositis pada kemoterapi sebelumnya, yaitu masing-masing $66.7 \%$ dan $80 \%$.

Menurut Cancer Care Nova Stovia atau CCNS (2008), mukositis dapat terjadi pada 45$80 \%$ pasien yang menjalani kemoterapi. Menurut Sutrisno, Dharmayuda \& Ren (2010); Mottalebnejad et al., (2008) menyatakan bahwa 30$70 \%$ pasien yang mendapatkan kemoterapi akan mengalami mukositis pada setiap siklus kemoterapi, sedangkan pada pasien yang menjalani transplantasi sumsum tulang 90\%-nya akan mengalami mukositis. Hal tersebut terjadi karena secara mikroskopis lingkungan flora normal di mukosa oral berubah dan terjadi berbagai peru- bahan dalam sel-sel epitel mukosa oral akibat kemoterapi. Setelah fase penyembuhan, mukosa oral kembali terlihat normal tetapi lingkungan mukosa secara signifikan telah berubah. Angiogenesis terus berlanjut setelah fase penyembuhan. Menurut Dodd et al., (2008) pasien akan memiliki risiko untuk mengalami mukositis berulang saat pasien mendapatkan kemoterapi berikutnya.

Berdasarkan hasil penelitian terlihat bahwa secara keseluruhan hampir seluruh responden atau sejumlah 21 orang (70\%) mendapatkan kemoterapi dengan tingkat mukosatoksik tinggi. Menurut Harris et al., (2008), kemoterapi anti kanker akan menyebabkan sel kanker serta beberapa jenis sel sehat yang juga sedang membelah atau tumbuh mengalami kerusakan. Namun sel kanker akan mengalami kerusakan lebih parah dibanding kerusakan pada sel sehat. Setelah beberapa periode 1-3 minggu sel sehat pulih dan sel kanker juga akan pulih kembali namun mengalami kerusakan, sehingga atas dasar inilah obat anti kanker dipergunakan. Mencegah kerusakan permanent dari sel sehat, maka obat kanker tidak bisa diberikan sekaligus tetapi dapat diberikan selama 4-8 siklus. Hal ini dimaksud untuk memulihkan sel sehat. Diantara sel sehat yang terkena akibat obat kemoterapi adalah sel mukosa, namun sel-sel tersebut akan mengalami perbaikan (recovery). Proses perbaikan sel mukosa tergantung dari jenis obat kemoterapi yang digunakan, biasanya 14 hari setelah pemberian obat kemoterapi tergantung jenis obat.

Distribusi responden berdasarkan status gizi, secara keseluruhan sebagian besar dari responden memiliki status gizi yang normal (53.3\%). Menurut uji homogenitas, kategori status gizi pada kelompok kontrol dan kelompok intervensi setara, dimana secara keseluruhan, sebagian besar responden memiliki status gizi normal. Hal ini membuktikan bahwa status gizi sebagai variabel potensial perancu telah dapat dikontrol, sehingga perbedaan yang bermakna pada skor mukositis antara kelompok kontrol dan kelompok intervensi tidak dipengaruhi status gizi.

Berbagai penelitian telah melaporkan hasil penelitian yang berbeda-beda terkait dengan status gizi dan hubungannya dengan terjadinya mukositis. Pasien dengan BMI yang tinggi seperti pada pasien dengan gizi normal atau gizi lebih justru lebih berpotensi mendapatkan mukositis karena dosis obat kemoterapi yang diterima lebih 
PROFESI (Profesional Islam): Media Publikasi Penelitian 2019; Volume 16; No 2.

Website: ejournal.stikespku.ac.id

banyak dari pasien dengan BMI yang rendah seperti pasien yang kurus atau sangat kurus. Hal tersebut terjadi karena pada BMI tinggi, rasio jaringan adiposa dan berat badan tubuh akan meningkat. Hal itu akan mempengaruhi distribusi obat kemoterapi dan farmakokinetiknya.

Menurut CCNS (2008) menyatakan bahwa pasien dengan status gizi buruk biasanya akan mendapatkan mukositis yang lebih berat karena sistem imun yang tidak bekerja optimal dan kurangnya zat gizi yang diperlukan untuk penyembuhan mukositis. Mukositis pasca kemoterapi dapat terjadi baik pada pasien dengan gizi normal, gizi kurang atau gizi lebih.

Hasil skor mukositis sebelum intervensi didapatkan bahwa rata-rata skor mukositis sebelum intervensi pada pasien kanker yang menjalani kemoterapi pada kelompok intervensi 8.80 dengan standar deviasi 0.62. Sedangkan hasil analisis data pada kelompok kontrol didapatkan bahwa rata-rata skor mukositis sebelum intervensi pasien kanker yang menjalani kemoterapi 8.91 dengan standar deviasi 0.64. Menurut Dodd, (2014) mengkategorikan hasil OAG dalam dua kategori yaitu tidak mukositis (normal) jika skor $\mathrm{OAG}<10$ dan mukositis jika skor $\mathrm{OAG} \geq 10$. Oleh sebab itu, secara umum hasil skor oral assessment guide (OAG) sebelum intervensi pada penelitian ini menunjukkan bahwa seluruh responden termasuk dalam kategori normal/tidak mukositis (skor <10).

Hasil skor mukositis setelah intervensi data didapatkan bahwa rata-rata skor mukositis sebelum intervensi pada pasien kanker yang menjalani kemoterapi pada kelompok intervensi 8.27 dengan standar deviasi 0.54. Sedangkan hasil analisis data pada kelompok kontrol didapatkan bahwa rata-rata skor mukositis sebelum intervensi pasien kanker yang menjalani kemoterapi 12.82 dengan standar deviasi 1.46.

\subsection{Analisis Bivariat}

Berikut ini adalah tabel uji normalitas data setiap variabel dan hasil analisis perbedaan ratarata skor mukositis sebelum dan setelah intervensi pada kelompok kontrol dan intervensi:
Tabel 4. Analisis Uji Normalitas Data Skor Mukositis Sebelum dan Setelah Intervensi (n1-n2: 15)

\begin{tabular}{lccc}
\hline Variabel & Intervensi & Kontrol & pValue \\
\hline Skor mukoitis & mean: 8.80 & mean: 8.91 & 0.402 \\
sebelum & mean: 8.27 & mean: 12.82 & 0.883 \\
Skor mukoitis & & & \\
setelah & & & \\
\hline
\end{tabular}

Tabel 5. Analisis Perbedaan Rata-rata Skor Mukositis Sebelum dan Setelah Intervensi Pada Kelompok Intervensi dan Kontrol (n1-n2: 15)

\begin{tabular}{lccccc}
\hline Variabel & Kelompok & $\mathrm{n}$ & Mean & SD & pValue \\
\hline Skor & & & & & \\
Mukusitis & Intervensi & 15 & 8.80 & 0.62 & 0.002 \\
- Sebelum & & 15 & 8.27 & 0.54 & \\
- Setelah & & & & & \\
& & & & & \\
- Sebelum & \multirow{2}{*}{ Kontrol } & 15 & 8.91 & 0.64 & 0.000 \\
- Setelah & & 15 & 12.82 & 1.46 & \\
\hline
\end{tabular}

Tabel 6. Analisis Perbedaan Rata-rata Skor Mukositis Setelah Intervensi Pada Kelompok Intervensi dan Kelompok Kontrol (n1-n2: 15)

\begin{tabular}{lccccc}
\hline Variabel & Kelompok & $\mathrm{n}$ & Mean & SD & $p$ Value \\
\hline $\begin{array}{l}\text { Skor } \\
\text { Mukositis }\end{array}$ & Intervensi & 15 & 8.27 & 0.54 & 0.000 \\
& Kontrol & 15 & 12.82 & 1.46 & \\
\hline
\end{tabular}

Berdasarkan hasil uji normalitas data didapatkan bahwa skor mukositis sebelum dan setelah intervensi pada kedua kelompok berdistribusi normal, dengan nilai $p$ value $>0.05$. Hasil analisis rata-rata skor mukositis sebelum dan setelah intervensi dapat disimpulkan bahwa terdapat perbedaan yang signifikan antara skor mukositis sebelum dan setelah intervensi pada kelompok intervensi dan kelompok kontrol. Skor mukositis setelah intervensi pada kelompok intervensi menunjukkan nilai rata-rata yang lebih rendah dibandingkan dengan skor mukositis sebelumnya, dengan selisih sebesar -0.53 , sedangkan pada kelompok kontrol skor mukositis setelah kemoterapi menunjukkan skor yang lebih tinggi dibandingkan dengan skor sebelum kemoterapi sebesar 3.91.

Hasil ini menunjukkan bahwa intervensi oral care dengan berkumur air kelapa muda memberikan hasil yang signifikan terhadap skor mukositis pada anak pasca kemoterapi. Penelitian Mokoginta et al., (2017) menyimpulkan bahwa berkumur air kelapa terbukti efektif untuk menurunkan $\mathrm{pH}$ saliva serta mengurangi mukositis. Menurut peneliti, hal ini terjadi karena 
PROFESI (Profesional Islam): Media Publikasi Penelitian

2019; Volume 16; No 2.

Website: ejournal.stikespku.ac.id

air kelapa memiliki berbagai zat yang sangat berguna untuk mengurangi mukositis dan mempercepat penyembuhan mukositis. Pada anak yang mendapatkan intervensi, dengan ber-kumur air kelapa muda selama 5 hari maka anak akan mendapatkan protocol oral care alami yang berfungsi sebagai agen topical, larutan kumur, agen stimulasi pertumbuhan jaringan, agen antiinflamasi, agen anti septic dan pelindung mukosa. Hal ini kemungkinan menyebabkan efek berkumur air kelapa muda secara statistik sangat signifikan untuk menurunkan efek kemoterapi berupa mukositis. Air kelapa muda merupakan salah satu bahan makanan atau minuman yang mengandung zat-zat yang diharapkan mampu mencegah mukositis, sehingga dapat mengatasi efek kemoterapi tersebut (NHS Foundation Trust, 2010; Yanwar dan Sutrisno, 2015).

Air kelapa muda mempunyai efek terapeutik yaitu sebagai minuman steril, yang mengandung antioksidan, anti inflamasi dan mineral berupa kalium, natrium, kalsium serta vitamin $\mathrm{C}$ dengan pH 5.5 (asam) (Runtunuwu, 2011; Yanwar dan Sutrisno, 2015). Air kelapa muda merupakan salah satu bahan makanan atau minuman yang mengandung zat-zat yang diharapkan mampu mencegah mukositis, sehingga dapat mengatasi efek kemoterapi tersebut.

Penelitian yang dilakukan oleh Farapti dan Sayogo (2014) tentang pengaruh berkumur air kelapa muda terhadap $\mathrm{pH}$ saliva menunjukan bahwa air kelapa muda berpengaruh dalam menurunkan $\mathrm{pH}$ saliva. Kandungan ion-ion, $\mathrm{pH}$, total padatan atau asam laktat serta reduksi yang terdiri dari fruktosa, glukosa dan asam amino dapat mempengaruhi perubahan $\mathrm{pH}$ saliva. Semakin banyak sumber asam-asam organik yang dapat dimetabolisme, maka semakin menurun pH saliva (Farapti dan Sayogo, 2014; Yanwar dan Sutrisno, 2015). Menurut Waworuntu, (2014), Ionisasi asam laktat pada air kelapa muda akan menghasilkan ion $\mathrm{H}+$ sehingga menyebabkan suasana asam pada saliva yaitu menurunkan $\mathrm{pH}$ dan mikrobakteri sulit untuk merkembang pada kondisi ini.

Kandungan air yang cukup tinggi dalam buah kelapa dapat membantu fungsi saliva dalam pembersihan mulut, sehingga menghambat perkembangbiakan bakteri merugikan dalam rongga mulut, serta vitamin $\mathrm{C}$ merupakan zat alami anti inflamasi, antibodi dalam menurunkan nyeri, memperbaiki sel atau jaringan yang rusak.

Efek teraupetik air kelapa muda dikarenakan air kelapa muda mengandung air kelapa sekitar $300 \mathrm{ml}$ dengan $\mathrm{pH}$ berkisar 3.5-6.1 yang menyebabkan bakteri sulit hidup pada kondisi ini (Farapti dan Sayogo, 2014) serta mengandung gula reduksi yang akan mengkonversi glukosa menjadi glucose acid yang menghambat pertumbuhan bakteri (Affilation, 2013). Menurut Farapti dan Sayogo (2014), air kelapa muda merupakan air steril, mengandung vitamin B (B1,B2, B3, B5, B6, B7, B9) dan vitamin C serta mengandung mineral berupa kalium, natrium, kalsium, Potasium dan magnesium. Kandungan berbagai zat didalam air kelapa menyebabkan air kelapa muda mampu mencegah cedera sel akibat agen kemoterapi, menjaga keutuhan mukosa mulut, membunuh mikroba, mempercepat pertumbuhan sel mukosa baru dan meningkatkan proses penyembuhan mukositis.

\section{SIMPULAN}

Gambaran responden pasien kanker yang menjalani kemoterapi sebagian besar memiliki riwayat pengalaman mukositis sebelumnya (73\%), hampir seluruh responden $(70 \%)$ mendapatkan kemoterapi dengan tingkat mukosatoksik tinggi, sebagian besar responden memiliki status gizi normal (53.3\%).

Terdapat perbedaan yang signifikan antara skor mukositis sebelum dan sesudah intervensi pada kelompok intervensi $(\mathrm{p}=0,002)$ dan kelompok kontrol $(\mathrm{p}=0,000)$.

Terdapat pengaruh berkumur air kelapa muda terhadap mukositis akibat kemoterapi pada anak yaitu pada kelompok intervensi terdapat penurunan skor mukositis yang signifikan sebesar 0.53 sedangkan pada kelompok kontrol terdapat peningkatan skor mukositis sebesar 3.91 ( $p$ value $=0,000$ ).

\section{SARAN}

Mempertimbangkan hasil penelitian ini sebagai rujukan untuk merancang atau memodifikasi standar asuhan keperawatan pada anak dengan penyakit kanker dalam intervensi keperawatan berupa program/protokol oral care pada anak selama anak menjalani program kemoterapi di rumah sakit. 
PROFESI (Profesional Islam): Media Publikasi Penelitian 2019; Volume 16; No 2. Website: ejournal.stikespku.ac.id

Mengintegrasikan materi tentang terapi komplementer dan terapi non-farmakologis dari berbagai hasil penelitian yang telah diterapkan dan terbukti efektif dalam menangani mukositis akibat kemoterapi pada anak dalam kurikulum sarjana keperawatan.

Mengadakan kerjasama dan membangun koordinasi yang baik antara institusi pendidikan keperawatan dengan institusi pelayanan kesehatan, serta industri terkait untuk mengembangkan penerapan hasil penelitian terkait intervensi keperawatan oral care dengan menggunakan agen-agen yang terbukti efektif sesuai dengan hasil-hasil penelitian untuk menangani mukositis akibat kemoterapi pada anak sebagai produk inovasi kampus.

\section{REFERENSI}

Affilation. (2013). The effect of coconut water on the salivary $\mathrm{pH}$ of the oral cavity among the selected Dentistry student of Cebu Doctors' University with induced acidity method AY 2012-2013. Thesis. Mandue: Cebu Doctors' University. 2013.p.1

Cancer Care Nova Stovia. (2008). Best practice guidelines for the management of oral complication from cancer therapy. California: Nova Stovia Goverment. Diperoleh melalui www.cancercare.ns.ca tanggal 13 Februari 2017.

Depkes RI. (2011). Press release hari kanker anak sedunia. Diperoleh dari http://www.tvl. com/press release hari kanker anak sedunia html tanggal 26 Februari 2017.

Dodd, M.J. (2014). The pathogenesis and characterization of oral mucositis associated with cancer therapy. Oncology Nursing Forum. 31(4):5-12.

Eiler, J., Berger, A.M., \& Petersen, M.C. (2004). Development, testing and application of oral assesment guide. Oncology Nursing Forum. 15: 325-330.

Farapti \& Sayogi, S. (2014). Air kelapa mudapengaruhnya terhadap tekanan darah. Jurnal CDK-223. 41 (12). Universitas Airlangga.
Harris, J.D., Eilers, J., Harriman, A., Cashavelly, B., \& Maxwell, C. (2008). Putting evidence into practice: Evidance based intervention for the management of oral mucositis. Clinical Journal of Oncology Nursing. 12(1): 141-147

Hockenberry, M.J., \& Wilson, D. (2009). Antiproliferative effect and of its polyphenols: a review. Journal of Biomedicine and Biotechnology. 9:1-13.

Keefe, D.M., Schubert, M.M., Elting, L.S., Sonis, S.T., Epstein, J.B., Raber-Durlacer, J., Migliorati, C.A. (2007). Update clinical practices guidlines for the prevention and treatment of mucositis. American Cancer Society. 109(5): 24-73.

Mokoginta, Z.P., Wowor, V.N.S., Juliatri. (2017). Pengaruh berkumur air kelapa muda terhadap $\mathrm{pH}$ saliva. Pharmacon Jurnal Ilmiah Farmasi. 6 (1). Universitas Samratulangi.

Mottalebnejad, M., Akram, S., Moghadamina., Moulana, Z., \& Omidi, S. (2008). The effect of topical application of pure honey on radiation-induced mucositis. The Journal of Contemporary Dental Pratice.

NHS Foundation Trust. (2010). Children's nursing oral hygine. London: Doncaster and Bassetlaw Hospital Release. Diakses melalui www.dhb.nhs.uk tanggal 1 Februari 2017.

Nursing, BC. (2006). Complementary and alternative health care: the role of the nurse. $\quad$ http://www.ncbi.nlm.nih.gov/ pubmed/12943134, diperoleh tanggal 21 Januari 2017.

Runtunuwu, S.D. (2011). Kandungan kimia daging dan air buah sepuluh tetua kelapa dalam komposit. Buletin Palma. 12 (1) : $58,61-2$.

Sutrisno H., Dharmayuda T.G., Ren R.A. (2010). Gambaran kualitas hidup pasien kanker limfoma non Hodgkin yang dirawat di RSUP Sanglah Denpasar (studi pendahuluan) http://www.ojs.unud.ac.id/ 
PROFESI (Profesional Islam): Media Publikasi Penelitian 2019; Volume 16; No 2.

Website: ejournal.stikespku.ac.id

index.php/jim/article/download/3952/294 4, diperoleh tanggal 13 Februari 2017.

Waworuntu, A. (2014). Efektifitas permen karet xylitol terhadap derajad keasaman saliva setelah mengkonsumsi minuman bersoda. Skripsi. Manado: Program Studi Pendidikan Dokter Gigi Fakultas Kedokteran Universitas Sam Ratulangi.
Yanwar, S.E., Sutrisno, A. (2015). Minuman probiotik dari air kelapa muda dengan strate bakteri asam laktat Lactobacilus casol. Jurnal Pangan dan Agroindustri. 3: 913 